\title{
An Analysis of Aid Information Management Systems (AIMS) in Developing Countries: Explaining the Last Two Decades
}

\author{
Kyung Ryul Park \\ London School of Economics \\ k.park5@1se.ac.uk
}

\begin{abstract}
Aid information management systems (AIMS) are information and communication technology (ICT) applications that enable donors and recipient governments to open and share aid data. Despite the popularity of AIMS and current trends favouring 'open aid', little research has been conducted in the field of ICT in the international aid sector. The purpose of this paper is to provide a critical discussion of AIMS. To achieve these objectives, the study explores 75 AIMS which have been implemented in 70 developing countries over the last two decades. Drawing on the idea of institutional isomorphism, this study offers a historical overview of AIMS and explains their driving forces and evolution. By using content analysis, it also provides an understanding of the main rhetoric inscribed in AIMS and how this has changed over time. In spite of significant attention given to new technologies and heavy investments made in AIMS, many cases have not achieved the anticipated outcomes that the rhetoric of AIMS promised, and even failed to reach sustainability (43\%). The analysis enables us to highlight the complexity of problems surrounding AIMS. This calls for a new approach to the way we promote and implement AIMS, as well as more in-depth study to understand institutional and political challenges in each context.
\end{abstract}

\section{Introduction}

The question of aid effectiveness has been raised in the international development arena and generated intense academic debate over the past decades [1]-[3]. Lack of aid transparency and coordination among stakeholders has been widely discussed as the main impediments to aid effectiveness [4]. Empirical evidence shows that coordination failure increases duplication of aid activities [5], inefficiency in aid delivery [6], undermines the quality of political institutions [7], [8], and raises administrative burdens in recipient countries [4]. In spite of dispute over the solution, there are still some stances that most aid scholars and practitioners would probably agree on: 1) aid information transparency is positioned at the core of the aid coordination debate, and 2) ICT can arguably contribute to better aid information management.

The main challenges of aid coordination are thought to be associated with information problems. Scholars have identified issues including the dissemination of quality information in a timely manner [5], [9], unwillingness to share information [10], mistrust and misinterpretation of information [11], and high coordination cost [10]. One way to overcome these challenges may be improving information, in particular on the donor's planned activities and budgets [12], [13]. A common underlying assumption is that "the comprehensive availability and accessibility of aid information in a timely, systematic and comparable manner" [14] would increase transparency and allow stakeholders to coordinate better. Opening and sharing basic aid information on the "three Ws of aid: who is doing what, where" is considered a prerequisite for better coordination [15], [16].

By this process of information rationalization, ICT is often perceived as an innovative tool to 1) enable countries to more effectively manage their aid activities and avoid overlaps with other donors [17], and 2) enhance donor-recipient coordination and help recipient governments plan and predict their budgets better, taking more ownership in the aid coordination mechanism and achieving better development outcomes, particularly in countries with higher aid dependency and where foreign aid forms a large part of their budget.

Based on a plethora of research and an international call for aid transparency and coordination, a number of ICT applications commonly referred to as aid information management systems (AIMS) have been developed and implemented in developing countries over the past two decades. In general, AIMS include software, websites or databases that store and process aid information on donors' activities, budgets, and development indicators. Scholars and practitioners advocate that such systems might have a huge positive 
impact in terms of transparency and managerial efficiency within government, promoting openness in aid process and enhancing aid coordination among stakeholders. However, what has been carried out in the field seems far from what was originally expected to be achieved by AIMS.

Despite the proliferation of AIMS and current trends favouring 'openness' in aid and development process [18], [19], little critical and structured research has been conducted in the field of information systems in international aid where different political and economic interests and institutional logics of various stakeholders inevitably collide. In particular, a review of all AIMS implemented in developing countries is non-existent. Within existing research, most research is from a technically rational, a-contextual perspective that focuses on AIMS as powerful tools for achieving more efficient ways of working and coordinating in the aid sector [18], [20], [21]. The international aid industry led by major donors and development agencies often favours this instrumental view as well [22]-[24]. Many models including the technology acceptance model [25] based on the notion of 'diffusionism' and technology transfer, have been provided in recent years that aim at describing an optimal process of IS implementation in developing countries [25], [26]. However, these models have received criticism in terms of 1) their technologically deterministic views, 2) their a-contextual and universalistic views [27], [28], and 3) their prioritization of innovator over imitator [29].

To address this gap in the literature, this paper proposes the use of institutional theory as an integrated approach to understand AIMS phenomena and their evolution. By conducting content analysis on 75 AIMS cases in 70 developing countries, the study provides an understanding of how the main rhetoric that AIMS endorse has changed over time, and presents results of a comprehensive review of 75 AIMS cases with respect to the types of systems, the functionalities and features, service providers, funders, as well as main driving forces.

In addition, the study identifies four important trends in the AIMS evolution. Firstly, AIMS have evolved from their initial adoption as an intra-agency PC-based system within governments to more transactional and integrated applications as web-based and open-data based systems recently. Secondly, the themes inscribed in AIMS have also evolved from a focus on 'managerialistic' to 'normative' agenda, then more recently to divergent values of 'civil' and 'business'. Thirdly, the processes of implementing AIMS are similar, and the challenges discussed are recurrent across context and time. Lastly, in spite of significant attention given to new technologies and heavy investments made in AIMS, many cases have not achieved the anticipated outcomes that the rhetoric of AIMS promised, and even failed to reach sustainability (43\%).

This analysis enables us to understand that the success of AIMS does not necessarily rely on the design and technological issues of AIMS, but more importantly on institutional and political factors. This also calls for a new approach to the way we promote and implement AIMS, as well as more in-depth study to understand the complexity of problems in the context of developing countries.

\section{Theoretical framework}

Institutional theory has attracted attention in information systems and ICT4D field as a relevant theoretical perspective [30]-[32]. The outcomes produced by ICT in developing countries can be contingent upon institutional factors and broad national characteristics and context, rather than technology adoption itself [27]. Activities in development, implementation, and use of ICTs are shaped by technical as well as social, organizational, cultural and other institutional factors. The pressures on the activities could come not only from rules, norms, and institutional logics embedded in the organization but also from the external world such as markets, donor agencies, and the international community. Organizations may react to the pressures by adopting a particular technology, or reforming their policy and practice to shape the technology. By doing so, they may achieve social legitimacy as well as good relationships with the external environment [33]. In this process, the organizations situated within one organizational field are more likely to have homogeneity in structure, process and practice. This concept of institutional isomorphism has been widely adopted in understanding the diffusion of a particular practice and technology across organizations [34]. This study applies this idea of institutional isomorphism to understand the diffusion of AIMS in the organizational field of international aid.

DiMaggio and Powell (1983) propose three institutional isomorphic mechanisms: coercive, normative, and mimetic [32]. These mechanisms could influence organizations in having similarity with peers and gaining institutional legitimacy [34], [35]. Coercive isomorphism means that an organization adopts a particular structure and practice due to formal and informal pressures from other influential organizations on which they are dependent. For instance, recipient governments that have entered into an either agreement or endorsed an international aid agenda could be more cooperative with the rules. 
Those countries reliant on more aid might follow the aid standards and goals set by the international aid community than other governments. The normative pressure primarily stems from the norms of a professional community. It influences organizations by advising and disseminating knowledge. For example, developing countries receiving consultancy and technical assistance from leading aid experts or agencies are more likely to follow ready-made solutions and adopt structures and practices suggested by these professionals. Academics and technical experts, in particular, at UNDP, OECD, and the World Bank are often in the position to influence recipient governments to endorse the political rhetoric on aid agenda and adopt AIMS. The mimetic isomorphism is encouraged when there is a high level of uncertainty or competition in the field. Organizations tend to imitate structures and practices of others within the field that they perceive to be more legitimate and successful. The rapid diffusion of AIMS after the international endorsement of aid transparency initiative such as the Paris Declaration and current trends favouring openness among developing countries can be understood as a result of the mimetic isomorphism. In addition, regional competition between aid-receiving countries could be a source of mimetic pressure.

Figure 1. Institutional isomorphism in the organizational field of international aid (developed for this study)

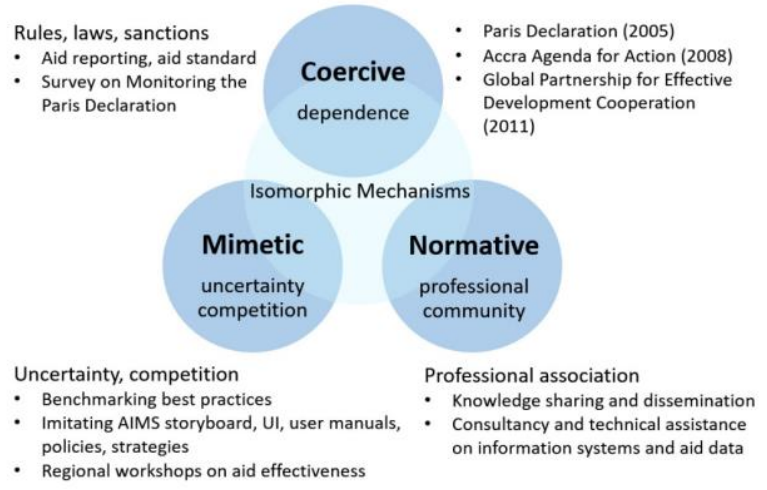

\section{Research methods}

The first stage of data collection was conducted by searching for any relevant quantitative and qualitative data on cases of AIMS in developing countries ${ }^{1}$. Although many donor countries and international development agencies have recently developed aid tracking platforms in order to increase transparency of their aid activities, the data collection for this study

\footnotetext{
1 Defining a developing country, I follow the definition of International Development Associate (IDA).
}

excludes such cases, and is limited to the AIMS implemented within developing countries. The first stage constituted archival research, including existing literature, reports, media, speeches, presentation files and project documents, mainly from January to April 2015. In the second stage, additional data collection was conducted. This included additional archival research and direct questioning of government officials (mainly from the Finance Ministry or Foreign Ministry) in 21 recipient countries. Government officials were contacted via email and informal conversation to ascertain whether the country currently has or previously had an AIMS. Later, in order to collect further data on AIMS, informal, semi-structured interviews were conducted with aid experts in donor agencies and international organizations, as well as with government officials during the period from August 2015 to February 2016.

Based on the data collected, this study discovered at least 75 cases of AIMS either currently or previously being used in 70 countries during the period from 1996 to 2015. For the analysis, the cases were screened through sourcing and visiting their URL, and checking whether they are still being used during the period mainly from April to May 2016. It also involved summarizing obtained project documents and user manuals. All relevant information such as AIMS URL, budget, government counterpart organization, funders, service providers, year of planning, implementation, shutdown (if applicable), and current status was analyzed. In addition, preliminary content analysis was conducted to identify different themes inscribed in AIMS by time, in order to construct the evolution of AIMS.

\section{Evolution of AIMS}

\subsection{Emergence of aid management and AIMS 1.0: PC-based systems}

The Organization for Economic Co-operation and Development (OECD) Creditor Reporting System (CRS) could be considered as an origin of AIMS. The CRS was initially established for tracing aid flow reported by the donor countries of OECD, known as the Development Assistance Committee (DAC) in 1973. It was not a complete nor timely database in the beginning, and it was only after the mid-1990s that the information started being widely used in recipient countries. Now, the twenty-nine members of the DAC submit their data on individual aid activities to the CRS and this is verified by OECD. It has served as the source of official donor statistics on aid information where each donor country of DAC supplies aid, and 
shows how it is spent in the recipient country. It remains the most reliable database for aid information at this time.

Based on the data collection of 75 cases, the very first AIMS implemented within a recipient country was the Donor Assistance Database in Russia in 1996. It was financed by the G7 and UNDP. The system was developed by Synergy International Ltd, but was aimed at being operated by the government to facilitate information flow among government agencies, while receiving technical support from USAID. Later, this PC-based AIMS was implemented in seven of the Commonwealth of Independent States (CIS).

It is not clear why the first AIMS were implemented in these regions of transitional economy, which was changing from a centrally planned economy toward a market economy. It is, however, generally accepted that the economy was then the priority of main donors and the target of neoliberal Structural Adjustment Programs (SAP) led by the World Bank and IMF [36], [37]. The underlying assumption of its Poverty Reduction Strategy Papers (PRSPs) was that higher recipient government engagement in designing development policy would lead to better aid management and greater ownership of fiscal policy. ICT-enabled aid management was considered a good tool for increasing managerial efficiency, interconnecting ministries and enhancing intragovernmental coordination. In addition, it was also based on the assumption that developing countries have a disadvantage in ICT and suffer from a 'digital divide', meaning a new form of inequality.

Due to limited access to data, it is hard to comprehend the isomorphic process of AIMS during this period. However, this early stage of AIMS may be understood as some degree of mimetic behavior within the transitional economy countries, while coercive and normative pressures for a particular AIMS seems to be less prevalent, compared to following generations.

\subsection{Institutionalization of the organizational field in international aid and AIMS 2.0: Web- based systems}

The global organizational field of international aid was gradually established among important stakeholders such as OECD DAC countries, international development agencies, recipient governments, non-governmental organizations (NGOs), and professional communities such as economists and IT consultants. The OECD DAC had played the most important role as a rule-making organization by leading the OECD Monitoring Survey and CRS reporting. Such powerful NGOs and research institutes played roles as rule-supporting organizations by creating indices on aid transparency and coordination and publishing reports and international rankings of countries.

Table 1. Stakeholders in the organizational field of aid

\begin{tabular}{|l|l|l|}
\hline Category & Stakeholder & Role \\
\hline $\begin{array}{l}\text { Donor } \\
\text { country }\end{array}$ & $\begin{array}{l}\text { Lending, funding AIMS } \\
\text { program, providing aid } \\
\text { information }\end{array}$ \\
\hline $\begin{array}{l}\text { Int'l dev } \\
\text { agency }\end{array}$ & $\begin{array}{l}\text { OECD Development } \\
\text { Assistance Committee } \\
\text { (DAC), World Bank, } \\
\text { UNDP, etc }\end{array}$ & $\begin{array}{l}\text { Rule-making, lending, } \\
\text { managing multi-donor trust } \\
\text { fund, technical support, } \\
\text { knowledge dissemination }\end{array}$ \\
\hline $\begin{array}{l}\text { Int'l forum } \\
\text { \& initiative }\end{array}$ & $\begin{array}{l}\text { High Level Forum on } \\
\text { Aid Effectiveness (HLF) } \\
\text { and Global Partnership } \\
\text { for Effective }\end{array}$ & $\begin{array}{l}\text { Rule-making, agenda } \\
\text { setting, political } \\
\text { commitment }\end{array}$ \\
\hline $\begin{array}{l}\text { Nevelopment Co- } \\
\text { operation (GPEDC) } \\
\text { governmen } \\
\text { tal agency }\end{array}$ & $\begin{array}{l}\text { Mega-philanthropist, } \\
\text { civil society organization } \\
\text { (CSO) }\end{array}$ & $\begin{array}{l}\text { Rule-supporting, } \\
\text { contractor }\end{array}$ \\
\hline $\begin{array}{l}\text { Recipient } \\
\text { country }\end{array}$ & Multinational IT & $\begin{array}{l}\text { Managing foreign aid } \\
\text { technical assistance }\end{array}$ \\
\hline $\begin{array}{l}\text { IS provider } \\
\text { corporations }\end{array}$ & $\begin{array}{l}\text { Rule-supporting, providing } \\
\text { consultation, knowledge } \\
\text { dissemination }\end{array}$ \\
\hline $\begin{array}{l}\text { Research } \\
\text { \& policy } \\
\text { institute }\end{array}$ & $\begin{array}{l}\text { Mainly institutes in } \\
\text { major donor countries }\end{array}$ \\
\hline
\end{tabular}

Based on a plethora of research and calls for effective aid in the international aid sector, the OECD donor countries built significant momentum towards improving aid effectiveness and reached a major milestone with the endorsement of the Paris Declaration on Aid Effectiveness in 2005 [38]. This was endorsed by 138 countries and 28 international organizations, and may be the most crucial impetus for diffusion of web-based AIMS. The Paris Declaration has been the most authoritative principle and practical road-map to improve aid transparency, imposing commitments to share aid information for enhanced transparency and coordination. Thus, the second generation of AIMS, while still based on the CRS as a main data source, were encouraged to be open to the public and developed as web-based system. Once the organizational field was established, it shaped the behaviors and organizational structures of its members. The institutional pressures drove countries to adopt shared norms and similar practices in aid management.

The main drivers for the implementation of webbased AIMS can be understood as both internal and external. Recipient governments increasingly seek to improve management of the aid they receive. However, more importantly, external institutional pressure played a critical role in allowing the isomorphic dynamics and adopting such AIMS in developing countries. Building on the notion of 'good governance', there has been external pressure calling for transparency in recipient 
governments [39]-[41]. This normative pressure was presented as moral and irresistible.

It is arguably believed that ICT implementation would enable good governance in aid management. As ICT penetration increased in developing countries, international development agencies and donor countries promoted an ICT-enabled public sector reform, commonly referred to as e-government. Working alongside the popularity of e-government projects, web-based AIMS were implemented in many recipient countries with the hopes of corruption reduction as well as enhanced aid coordination.

Mimetic isomorphism seems relevant to understanding, in particular, the early time period of web-based AIMS. Findings show that most web-based AIMS in this period were homogenous in terms of user manuals, project documents, functionalities, and even web design of AIMS. This may have resulted from the two main service providers and related international development agencies. The uncertainty of the period, however, was a crucial force that encouraged imitation right after the Paris Declaration. When 'organizational technologies are poorly understood, when goals are ambiguous or when the environment creates symbolic uncertainty', mimetic process occurs [30]. By the Accra Action Plan in Ghana in 2008, the goals of the Paris Principles and the role of AIMS to achieve them were poorly understood, both in policy terms and as a practical road-map in aid management. However, the web-based AIMS were mostly implemented in this period between 2005 and 2008.

Coercive isomorphism seems considerable as well in this period. The OECD Survey on Monitoring Paris Declaration provided formal rules on aid management and reporting. The survey assessed the effectiveness of aid by using 12 suggested criteria. 34 developing countries and 55 donors participated in the survey in 2006, and 78 countries in the 2011 survey. In this process, recipient countries and donor agencies were encouraged to use AIMS in conducting the survey. This pressure and the formal rules such as timely reporting according to standardized questionnaires and the official peer review process by OECD increased coercive pressures on the adoption of AIMS.

The World Bank and UNDP promoted the adoption of AIMS in recipient countries, and provided technical assistance for the implementation of AIMS. Two major systems on the market have become the Development Assistance Database (DAD) developed by Synergy International Systems, and the Aid Management Platform (AMP) developed by Development Gateway. Development of these two systems began around 2005 in response to the Paris Declaration and resulted in implementations in more than 35 countries.
In addition to this, international development agencies and rule-supporting research institutions helped to further institutionalize an organizational field. These professional communities created normative pressures on recipient countries by disseminating cases of 'best practice' of AIMS and developing indices such as the Aid Transparency Index (ATI) and the Quality of ODA (QOODA).

\subsection{AIMS 3.0: Open data based systems}

In recent years, new opportunities and challenges in aid management have risen and prompted a more technologically sophisticated AIMS including geographic information systems (GIS) and open data covering and processing more detailed and inclusive aid information. This study identifies the following four reasons as key drivers for such demand.

First, the aid ecosystem has changed dramatically and become more complex due to the proliferation of new donors [42], [43] and aid heterogeneity increasing in type and modality [44]. New mega philanthropists, non-DAC countries such as BRICs and even SouthSouth cooperation are now providing significant amounts of aid of various types across the world. This challenge questions the validity of the current definition of ODA [45] and calls for a more extensive version of AIMS that covers new donors and diverse projects which have not been included on the CRS.

Second, most of the poorest of the poor no longer live in low income countries (LICs), but rather live in middle income countries (MICs) [46], [47]. This phenomenon raises important questions about the current model of aid management and how aid should be allocated to the poorest in non-poor countries. This new geography of global poverty demands subnational aid targeting and better management within a country by using sub-national open data and an advanced geographic information system (GIS) and geospatial analysis.

Third, many governments, cities and international organizations across the world have been embracing the idea of 'openness': establishing ICT platforms, launching open data initiatives with impressive speed, and making their information publicly available for reuse and dissemination. The common underlying assumption that openness contributes to transparency and accountability has given rise to popularity of the concept of open development in the international aid sector [18], [19] and provoked the question of how open data can contribute to better aid management and coordination.

Fourth, there has been considerable enthusiasm for citizen engagement in development processes [48], [49]. Stakeholders emphasize beneficiary feedback in 
the design, implementation, monitoring and evaluation of development programs. Initial studies of egovernment in developing countries focused on the narrow concept of bridging this digital divide, in terms of physical access to the internet and identified technology as a means. However, the notion of a digital divide has extended beyond the access to information to embrace the broader aspects of human development [50] and to apply ICT for social wellbeing, education and citizen engagement in aid activities. With this backdrop, there is growing interest in how ICT and open data contribute to citizen participation and closing the feedback loop [51], and how the beneficiary feedback mechanism can be incorporated into AIMS.

The importance and potential of open data has been recognized in the establishment of a new international aid agenda including the International Aid Transparency Initiative (IATI) and the Sustainable Development Goals (SDGs). These international calls have been followed by the implementations of open data based AIMS in many developing countries as well as donors' own open aid platforms. However, key issues remain unanswered: to what extent information sharing contributes to better aid coordination and enhanced development outcomes, and how open data influences information sharing in the field of international aid.

Table 2. The evolution of AIMS (1995-2015)

\begin{tabular}{|c|c|c|c|}
\hline & AIMS 1.0 & AIMS 2.0 & AIMS 3.0 \\
\hline & PC-based & Web-based & Open data based \\
\hline Time & 1995- & $2005-$ & 2011- \\
\hline Themes / 'keywords' & & & \\
\hline Managerialistic & \multirow[t]{2}{*}{$\mathrm{O}$} & \multirow[t]{2}{*}{0} & \multirow[t]{2}{*}{$\mathrm{O}$} \\
\hline $\begin{array}{l}\text { 'efficiency, cost- } \\
\text { effectiveness, reform' }\end{array}$ & & & \\
\hline $\begin{array}{l}\text { Socio-political, } \\
\text { normative }\end{array}$ & \multirow[t]{2}{*}{$\bar{X}$} & \multirow[t]{2}{*}{$\mathrm{O}$} & \multirow[t]{2}{*}{$\mathrm{O}$} \\
\hline $\begin{array}{l}\text { 'aid effectiveness, } \\
\text { coordination, ownership, } \\
\text { transparency, } \\
\text { accountability' }\end{array}$ & & & \\
\hline Business & \multirow[t]{2}{*}{$\mathrm{X}$} & \multirow[t]{2}{*}{$\mathrm{X}$} & \multirow[t]{2}{*}{$\mathrm{O}$} \\
\hline $\begin{array}{l}\text { 'Business, company, } \\
\text { job, investment, } \\
\text { entrepreneurship' }\end{array}$ & & & \\
\hline Civil & \multirow[t]{2}{*}{$\mathrm{X}$} & \multirow[t]{2}{*}{$\mathrm{X}$} & \multirow[t]{2}{*}{$\mathrm{O}$} \\
\hline $\begin{array}{l}\text { participation, citizen } \\
\text { engagement, openness } \\
\text { culture, democracy' }\end{array}$ & & & \\
\hline Target users & $\begin{array}{l}\text { Governmen } \\
\text { t officers }\end{array}$ & $\begin{array}{l}\text { + donor agency } \\
\text { workers, } \\
\text { academia, media }\end{array}$ & $\begin{array}{l}\text { + public users } \\
\text { (citizens, CSOs), } \\
\text { private sector }\end{array}$ \\
\hline Type of services & Database & $\begin{array}{l}\text { Geographic } \\
\text { information } \\
\text { system }\end{array}$ & $\begin{array}{l}\text { Linked open data \& } \\
\text { subnational dev } \\
\text { indicators, reuse and } \\
\text { redistribution, open } \\
\text { API standard }\end{array}$ \\
\hline $\begin{array}{l}\text { Aid data reporting } \\
\text { standard }\end{array}$ & CRS & CRS & CRS, IATI \\
\hline
\end{tabular}

\begin{tabular}{|l|l|l|l|}
\hline Milestones & $\begin{array}{l}\text { Donor's } \\
\text { priority in } \\
\text { transitional } \\
\text { economies, }\end{array}$ & $\begin{array}{l}\text { HLF on Aid } \\
\text { Effectiveness } \\
(2002), \text { Paris } \\
\text { Declaration } \\
\text { CIS (1991) }\end{array}$ & $\begin{array}{l}\text { Open data initiatives } \\
\text { and Open } \\
\text { Government } \\
\text { Partnership (2010) }\end{array}$ \\
\hline Major tension \& & Paper-based & Different & Aid heterogeneity, \\
challenges & vs IT & political, & complexity, gaps \\
& enabled & economic & bet'n supply and \\
& demand, confusion \\
& administrati & interests and & in aid standards \\
& perceptions & \\
& bureaucratic & between & \\
& resistance & stakeholders & \\
\hline
\end{tabular}

\section{Discussion}

The study finds 75 AIMS cases in 70 developing countries and identifies the diffusion of AIMS in developing countries, categorized in Table 4 . The 75 cases are classified into three categories: A) relatively active and being used, B) accessible URL but rarely being used, C) implemented once but shut down.

The category A refers to systems which were last updated within the most recent six-month period (December 2015 to May 2016). An update could mean new data input regarding a new project, disbursement report, or any data revision, as well as the system's software upgrades. However, the criteria do not take into account the frequency of data inputs in the system, or quality of information. Among 75 cases, only 12 cases are identified as category A: Nepal, Chad, Malawi, Senegal, Honduras, Kenya, Rwanda, Ukraine, Cambodia, Myanmar, Philippines, and Bolivia. Although the criteria for distinction between category $\mathrm{A}$ and $\mathrm{B}$ are not clear-cut, at least these 12 cases have recently updated and been in usage. However, 'last update' could mean merely upgrading websites or uploading data without any strategic purpose. Thus, the actual number of cases that are actively being used may be lower. Furthermore, on the demand side, there is lack of evidence of usage by the originally targeted users, particularly citizens in recipient countries. In order to further assess the usage and impact of AIMS, closer empirical scrutiny of each system is needed.

The category B, "accessible but rarely being used", refers to systems which have had no updates within the most recent six-month period (December 2015 to May 2016), although the URL is still accessible. There are 27 cases of AIMS with accessible URLs, but without any recent data provision or evidence of usage. These cases use different kinds of platforms and are spread across all regions.

The category C, "implemented once but shut down", refers to systems of which the study confirms the implementation of AIMS in a particular country through document analysis and interview results, but the URL could no longer be accessed. In some cases, the URL addresses are not even traceable. There are a 
total of 32 cases of AIMS being shut down. It represents $43 \%$ of the cases being involved in the research. It happened to cases within all different regions, with different service providers. Based on this analysis, it was interesting to discover that many AIMS implemented in developing countries had not achieved expected outcomes or even sustainable usage, in spite of heavy investments made. It seems many of them had been shut down without any thoughtful reflection and investigation into why they failed to achieve expected coordination goals or remain in operation.

The high rate of failure in information systems has often been discussed, in particular, 1) in the public sector that drives and manages the majority of ICT initiatives [52], [53], and 2) in the context of developing countries [54], [55]. Heeks (2003) estimates that $34 \%$ of ICT projects in developing countries are total failures, while $50 \%$ are partial failures, and only $15 \%$ succeed. The evaluation from the World Bank's Independent Evaluation Group is not different. This ascertains that more than $70 \%$ of its ICT projects are failures [57]. There is, however, no distinctive boundary in defining success or failure as the evaluation process and its criteria depend on individual perspectives [58], [59]. Although ascription of failure maybe socially constructed and diversified, this study defines a failure of AIMS as a permanent shutdown of the system within a relatively short period of time (1-5 years) after implementation, without any visible transformation, left-over innovation, or thoughtful reflection and evaluation.

As discussed in section 4, this study explains the emergence and implementation of the international aid sector as an organizational field, and identifies three different generations in the evolution of AIMS. Firstly, PC-based AIMS in transitional economies; secondly, web-based AIMS since the establishment of the Paris Principle in 2005; thirdly, and most recently open data AIMS based on the popular notions of 'open aid'. As AIMS have evolved from the initial adoption as an intra-system in recipient governments to more transactional and integrated applications as web-based and open data based systems, the themes inscribed in AIMS have also evolved. This illustrates the evolution from a 'managerialistic' to a 'socio-political' theme and more recently adding 'civil', 'participatory' and 'business' themes as shown in Table 2. The target of users has also been expanded from government officials to aid workers and policy makers of stakeholders, and finally to citizens. However, these diversified target audiences created challenges in usage, and questions about how to enhance user experiences effectively.

Based on review of three project documents, four user manuals and three evaluation reports from seven
AIMS cases, there is significant homogeneity in AIMS in terms of functionalities and implementation processes. Although it could not be generalized, the common process of AIMS implementation follows seven stages; 1) political process, 2) financial process, 3) design/development, 4) data input, 5) implementation, 6) usage and evaluation, and 7) policy, as shown in Table 3.

Table 3. Process and seven common stages of AIMS

\begin{tabular}{|c|c|c|}
\hline Stage & Key elements & Key questions \\
\hline $\begin{array}{l}\text { 1.Political } \\
\text { Process }\end{array}$ & $\begin{array}{l}\text { - Sharing the needs of } \\
\text { AIMS among stakeholders } \\
\text { - Decision-making process } \\
\text { - Donor's commitment to data } \\
\text { provision } \\
\text { - External/international pressure } \\
\text { - Aid data standard: CRS, IATI }\end{array}$ & $\begin{array}{l}\text { - Who are the } \\
\text { stakeholders? } \\
\text { - Who drives AIMS? } \\
\text { - Is there relevant legal } \\
\text { framework / regional or } \\
\text { int'l aid agreement? }\end{array}$ \\
\hline $\begin{array}{l}\text { 2.Financial } \\
\text { Process }\end{array}$ & $\begin{array}{l}\text { - Financial commitment (bilateral } \\
\text { ODA, multi-donor trust fund) } \\
\text { - Hiring IT consultants or } \\
\text { vendors and staffing } \\
\text { - Normally, donor provides fund } \\
\text { to gov; gov takes ownership. }\end{array}$ & $\begin{array}{l}\text { Who provides funding? } \\
\text { Who operates and } \\
\text { manages the AIMS? }\end{array}$ \\
\hline $\begin{array}{l}\text { 3. Design \& } \\
\text { Development }\end{array}$ & $\begin{array}{l}\text { - Government-driven vs ready- } \\
\text { made AIMS } \\
\text { - Meetings with stakeholders } \\
\text { - Considering the existing data } \\
\text { standards and classification in } \\
\text { data architecture } \\
\text { - Considering the existing } \\
\text { government information } \\
\text { systems and compatibility } \\
\text { - Ways of data visualization } \\
\text { - Beta version test }\end{array}$ & $\begin{array}{l}\text { - Who are the users? } \\
\text { - What software, } \\
\text { technical features? - } \\
\text { GIS, linked data, API } \\
\text { - Who provides and } \\
\text { enters data, what kind } \\
\text { of data in what format? } \\
\text { How to make AIMS } \\
\text { compatible with } \\
\text { existing system? }\end{array}$ \\
\hline 4.Data Input & $\begin{array}{l}\text { - Donors' provision of data } \\
\text { (sometimes with ID/password) } \\
\text { - Data workshop donor agencies } \\
\text { - Feedback mechanism with } \\
\text { providers } \\
\text { - Data quality control }\end{array}$ & $\begin{array}{l}\text { - Who is donor focal } \\
\text { point? } \\
\text { - Who does data quality } \\
\text { control? } \\
\text { - Normally, donors } \\
\text { provide data, gov } \\
\text { manages, rearranges, } \\
\text { and does quality control } \\
\end{array}$ \\
\hline $\begin{array}{l}5 . \\
\text { Implementati } \\
\text { on }\end{array}$ & $\begin{array}{l}\text { - Launch of AIMS, normally } \\
\text { with a fancy ceremony and } \\
\text { vision announcement by high- } \\
\text { level policy makers } \\
\text { - Marketing and media coverage } \\
\text { - Workshop, capacity } \\
\text { development programs } \\
\text { - Data management } \\
\end{array}$ & $\begin{array}{l}\text { - How to advertise } \\
\text { AIMS? } \\
\text { How are social, } \\
\text { political, cultural } \\
\text { contexts considered? }\end{array}$ \\
\hline $\begin{array}{l}\text { 6. Usage \& } \\
\text { Evaluation }\end{array}$ & $\begin{array}{l}\text { - Encouragement of data use, re- } \\
\text { use (open data) } \\
\text { - Feedback process } \\
\text { - Sustainability } \\
\text { - Data update } \\
\text { - Research and publication, best } \\
\text { practices (mainly by donors) }\end{array}$ & $\begin{array}{l}\text { - How to sustain AIMS? } \\
\text { - How to update data? } \\
\text { - How to promote usage? } \\
\text { How to scale up best } \\
\text { practices to other } \\
\text { contexts? } \\
\text { - How to promote citizen } \\
\text { engagement? (most } \\
\text { recent AIMS) }\end{array}$ \\
\hline 7. Policy & $\begin{array}{l}\text { - Expected outcomes } \\
\text { (transparency, coordination, } \\
\text { accountability) } \\
\text { - Further legislation and policy } \\
\text { dialogue }\end{array}$ & $\begin{array}{l}\text { How to enhance actual } \\
\text { aid coordination and } \\
\text { accountability? }\end{array}$ \\
\hline
\end{tabular}


The challenges commonly discussed in the evaluation reports are similar and recurrent across cases and time. In general, the problem-solving capacity of ICTs as a tool were over-estimated, while the political and institutional arrangements required for implementing and maintaining the systems were underestimated. In addition, technical issues are more often discussed than social, institutional and political issues in AIMS.

ICT4D research in the context of AIMS has been unexplored. From the analysis of 75 AIMS cases and assessment of gaps within current AIMS research, this paper proposes major areas of future research opportunities as below.

Firstly, the current development and implementation of AIMS focuses heavily on data transparency, and technical solutions from a managerial perspective. However, there is a wide gap between the technical rationale of AIMS and actual outcomes, as well as, the rhetoric and stakeholders' actual action. These call for research highlighting political and institutional challenges surrounding AIMS and understanding the complexity of the problems.

Secondly, documents concerning AIMS have only focused on their practice and application rather than on academic rigor and theory building. In spite of the global popularity of AIMS and the current open data phenomenon, the following questions remain unanswered: to what extent do information sharing and

\section{References}

[1] D. Moyo, Dead Aid: Why aid is not working and how there is another way for Africa. London: Penguin, 2008.

[2] W. Easterly, “The White Man's Burden,” Lancet, vol. 367. p. 2060, 2006.

[3] J. Sachs, The end of poverty, vol. 12 Suppl 1. New York: The Penguin Press, 2005.

[4] A. Bigsten and S. Tengstam, "International Coordination and the Effectiveness of Aid," World Dev., vol. 69, pp. 75-85, Jan. 2015.

[5] M. Halonen-akatwijuka, "Coordination Failure in Foreign Aid,” B . E . J. Econ. Anal. Policy, vol. 7, no. 1, 2007.

[6] S. Djankov, J. G. Montalvo, and M. Reynal-Querol, "Aid with multiple personalities," J. Comp. Econ., vol. 37, no. 217-229, 2009.

[7] S. Knack and A. Rahman, "Donor fragmentation and bureaucratic quality in aid recipients," J. Dev. Econ., vol. 83, no. 1, pp. 176-197, May 2007.

[8] E. R. Morss, "Institutional destruction resulting from donor and project proliferation in Sub-Saharan African countries," World Dev., vol. 12, no. 4, pp. 465-470, Apr. 1984.

[9] M. Jerven, "The relativity of poverty and income: How reliable are African economic statistics?," Afr. Aff. (Lond)., vol. 109, no. November, pp. 77-96, 2009.
ICT contribute to enhanced aid coordination and better development outcome? more importantly, how can the logic of open aid data be theoretically linked to the research stream of ICT4D? In order to even attempt to fill the gap, it requires a better understanding of the theoretically missing links between open data, information sharing and how they improve coordination in the aid sector.

Thirdly, by conceptualizing AIMS as a set of sociotechnical domains in which the varying political and economic interests of stakeholders' inevitably collide, further research would be required to shed light on the socio-political context and institutional challenges that account for conditions of success and failure in case.

Lastly, AIMS should be seen as an ecosystem including diverse actors within a supply-demand chain. ICTD researchers often point out that ICT initiatives cannot work properly if end users are not able to use the services. This study identifies most AIMS have focused on implementation but failed to achieve sustainability in usage. We need to have a better understanding on the demand side of AIMS, in particular, how to engage citizens in the development process. Future studies should question what incentivizes or constrains usage within the demand side, which group can be empowered within AIMS ecosystems, and whose voice can be reflected to make the aid process more inclusive.

[10] T. Ngamassi, E. Maldonado, K. Zhao, H. Robinson, C. Maitland, and A. Tapia, "Exploring Barriers to Coordination between Humanitarian NGOs," Int. J. Inf. Syst. Soc. Chang., vol. 2, no. 2, pp. 1-25, Jan. 2011.

[11] D. J. Saab, A. Tapia, C. Maitland, E. Maldonado, and L.-M. N. Tchouakeu, "Inter-organizational Coordination in the Wild: Trust Building and Collaboration Among Field-Level ICT Workers in Humanitarian Relief Organizations," Volunt. Int. J. Volunt. Nonprofit Organ., vol. 24, no. 1, pp. 194213, Apr. 2012.

[12] J. Powell and F. Michael, "The Swarm Principle? A Sub-national Spatial Analysis of Donor Coordination in Sub-Saharan Africa," Brigham Young Univ., pp. 134, 2011.

[13] A. Rahman and Y. Sawada, "Can donor coordination solve the aid proliferation problem?," Econ. Lett., vol. 116, no. 3, pp. 609-612, Sep. 2012.

[14] S. Moon and S. Williamson, "Greater Aid Transparency: Crucial for Aid Effectiveness," London, 2010.

[15] L. Chandy and H. Kharas, "Why Can't We All Just Get Along? The Practical Limits to International Development Cooperation," J. Int. Dev., vol. 23, pp. 739-751, 2011.

[16] L. Wenar, "Accountability in International Development Aid," Ethics Int. Aff., vol. 20, no. 1, pp. 1-23, Mar. 2011.

[17] A. Ghosh and H. Kharas, "The Money Trail : 

D. Linders, "Towards open development: Leveraging open data to improve the planning and coordination of international aid," Gov. Inf. Q., vol. 30, no. 4, pp. 426-434, Oct. 2013.

[19] M. Smith and K. M. A. Reilly, Open Development. Boston: MIT Press, 2014.

[20] C. Weaver, S. Davenport, and J. Baker, "Malawi's Open Aid Map," 2014.

[21] M. J. Tierney, D. L. Nielson, D. G. Hawkins, J. T. Roberts, M. G. Findley, R. M. Powers, B. Parks, S. E. Wilson, and R. L. Hicks, "More Dollars than Sense: Refining Our Knowledge of Development Finance Using AidData," World Dev., vol. 39, no. 11, pp. 1891-1906, Nov. 2011.

[22] OECD \& UNDP, "Role of Aid Information Management Systems in Implementing the Paris Declaration on Aid Effectiveness at the Country Level," Paris, 2006.

[23] UNDP, “Comparative Experience Aid Information Management Systems in Post-Conflict and Fragile Situations," 2010.

[24] Synergy International Systems, "Better Data, Better Aid ? Practical Guidance Note on Aid Information Management Systems Contents," 2009.

[25] F. D. Davis, R. P. Bagozzi, and P. R. Warshaw, "User Acceptance of Computer Technology: A Comparison of Two Theoretical Models.," Manage. Sci., vol. 35, pp. 982-1003, 1989.

[26] S. . Al-Gahtani, "Computer technology adoption in Saudi Arabia: Correlates of perceived innovation attributes," Inf. Technol. Dev., vol. 10, no. 1, pp. 5769, 2003.

[27] C. Avgerou, Information Systems and Global Diversity. New York: Oxford University Press, 2002.

[28] Walsham, Making a World of Difference: IT in a Global Context. Chichester, UK: John Wiley, 2001.

[29] T. Mcmaster and D. Wastell, "Diffusion - or delusion? Challenging an IS research tradition," Inf. Technol. People, vol. 53, no. May 2015, 2006.

[30] W. L. Currie, "Institutional isomorphism and change: The national programme for IT," J. Inf. Technol., vol. 27, no. 3, pp. 236-248, 2012.

[31] C. Avgerou, "IT and organizational change: an institutionalist perspective," Inf. Technol. People, 2000.

[32] L. F. Luna-Reyes and J. R. Gil-Garcia, "Using institutional theory and dynamic simulation to understand complex e-Government phenomena," Gov. Inf. Q., vol. 28, no. 3, pp. 329-345, 2011.

[33] J. W. Meyer and B. Rowan, "Institutionalized Organizations: Formal Structure as Myth and Ceremony," Am. J. Sociol.,vol.83, no.2, p. 340, 1977.

[34] P. DiMaggio and W. W. Powell, "The Iron Cage Revisite: Institutional Isomorphism and Collective Rationality in Organizational Fields," Am. Sociol. Rev., vol. 48, no. 2, pp. 147-160, 1983.

[35] P. Di Maggio and W. Powell, The New Institutionalism and Organizational Analysis. Chicago University Press, 1991.

[36] J. Roaf, R. Atoyan, and K. K. Bikas Joshi, "25 Years of Transition: post-communist Europe and the IMF," 2014.

[37] World Bank, "Poverty, Inequality, and Social Policy in Transition Economies," Washington DC, 1999.
[38] OECD, "Paris Declaration on the Aid Effectiveness," Paris, 2005.

[39] C. Burnside and D. Dollar, "Aid, Policies, and Growth: Revisiting the Evidence," O-2834, 2004.

[40] S. Madon, e-Governance for Development: A Focus on Rural India. London: Palgrave Macmillan, 2009.

[41] World Bank, Knowledge for Development. Washington DC: The World Bank, 1998.

[42] A. Acharya, A. T. F. de Lima, and M. Moore, "Proliferation and fragmentation: Transactions costs and the value of aid," J. Dev. Stud., vol. 42, no. 1, pp. 1-21, Jan. 2006.

[43] U. Burcky, "Trends in In-country Aid Fragmentation and Donor Proliferation: An Analysis of Changes in Aid Allocation Patterns between 2005 and 2009," 2011.

[44] G. Mavrotas, "Aid heterogeneity: looking at aid effectiveness from a different angle," J. Int. Dev., vol. 17, no. 8, pp. 1019-1036, Nov. 2005.

[45] J. Severino and O. Ray, "The End of ODA : Death and Rebirth of a Global Public Policy," 167, 2009.

[46] A. Sumner, "Where Do The Poor Live?," World Dev., vol. 40, no. 5, pp. 865-877, May 2012.

[47] R. Kanbur and A. Sumner, "Poor Countries or Poor Poeple? New Geography of Global Poverty," Ithaca, 2011.

[48] World Bank, Closing the Feedback Loop. Washington DC: World Bank, 2014.

[49] R. Chambers, Whose Reality Counts? Putting the Last First (London: ITDG Press, 1997). London: ITDG Press, 1997.

[50] A. Sen, Development as Freedom. Oxford: Oxford University Press, 1999.

[51] R. Wittemyer, S. Bailur, N. Anand, K.-R. Park, and S. Gigler, "New Routes to Governance: A Review of Cases in Participation, Transparency, and Accountability," in Closing the Feedback Loop: Can Technology Bridge the Accountability Gap?, Washington DC: World Bank, 2014.

[52] B. J. Berman and W. J. Tettey, "African states, bureaucratic culture and computer fixes," Public Adm. Dev., vol. 21, no. 1, pp. 1-13, 2001.

[53] R. Heeks, "Achieving Success/Avoiding Failure in eGovernment Projects," 2004.

[54] R. Heeks, "Information Systems and Developing Countries: Failure, Success, and Local Improvisations," Inf. Soc., vol. 18, no. 2, pp. 101112, Mar. 2002.

[55] S. Sahay and C. Avgerou, "Introducing the Special Issue on Information and Communication Technologies in Developing Countries," Inf. Soc., vol. 18, no. 2, pp. 73-76, 2002.

[56] R. Heeks, "Most eGovernment-for-development projects fail: how can risks be reduced?," Manchester, 2003.

[57] The Independent Evaluation Group, "Capturing Technology for Development: An evaluation of world bank group activities in ICT," Washington DC, 2011.

[58] M. Wilson and D. Howcroft, "Re-conceptualising failure: social shaping meets IS research," Eur. J. Inf. Syst., vol. 11, no. 4, pp. 236-250, 2002.

[59] E. Bartis and N. Mitev, "A Multiple Approach to Information Sytems failure: A Successful System that Failed," Eur. J. Inf. Syst., vol. 17, no. 2, 2008. 
Table 4. Aid information management systems in developing countries

\begin{tabular}{|c|c|c|c|c|}
\hline Region & $\begin{array}{l}\text { [A] Relatively active and } \\
\text { being used }\end{array}$ & [B] Accessible but rarely being used & [C] Implemented once but shutdown & Service Provider \\
\hline Sub Saharan Africa & Chad, Malawi, Senegal & $\begin{array}{l}\text { Burkina Faso, Côte d'Ivoire, Democratic } \\
\text { Republic of Congo, Ethiopia, Madagascar, } \\
\text { Mozambique, Tanzania, Uganda }\end{array}$ & $\begin{array}{l}\text { Burundi(1), Gambia, Guinea Bissau, Liberia, Niger, } \\
\text { Somalia, South Sudan, Togo }\end{array}$ & \multirow[t]{6}{*}{$\begin{array}{l}\text { Development } \\
\text { Gateway }\end{array}$} \\
\hline \multicolumn{4}{|l|}{ MENA } & \\
\hline East Asia \& Pacific & & Laos, Timor-Leste & & \\
\hline South Asia & Nepal & & & \\
\hline $\begin{array}{l}\text { Latin America and } \\
\text { Caribbean }\end{array}$ & Honduras & Haiti & Bolivia(1), Nicaragua & \\
\hline $\begin{array}{l}\text { Europe and Central } \\
\text { Asia }\end{array}$ & & Kosovo, Kyrgyz Republic(2), Moldova & & \\
\hline Sub Saharan Africa & Kenya, Rwanda & $\begin{array}{l}\text { Burundi(2), Cameroon, Central African } \\
\text { Republic, Comoros, Lesotho, Mauritania, } \\
\text { Nigeria, Sierra Leone }\end{array}$ & Somaliland, Zambia & \multirow[t]{6}{*}{$\begin{array}{l}\text { Synergy } \\
\text { International }\end{array}$} \\
\hline MENA & & Iraq,Yemen & Lebanon & \\
\hline East Asia \& Pacific & & Solomon Islands & $\begin{array}{l}\text { Indonesia(1)*, Papua New Guinea, Philippines(1), } \\
\text { Thailand*, Vietnam, }\end{array}$ & \\
\hline South Asia & & Afghanistan, Sri Lanka* & India, Maldives*, Pakistan & \\
\hline $\begin{array}{l}\text { Latin America and } \\
\text { Caribbean }\end{array}$ & & & Guatemala & \\
\hline \multirow[t]{3}{*}{ Europe } & Ukraine & Macedonia, Tajikistan & $\begin{array}{l}\text { Armenia, Georgia, Kazakhstan, Kyrgyz Republic(1), } \\
\text { Russia, Turkmenistan, Uzbekistan }\end{array}$ & \\
\hline & $\begin{array}{l}\text { Cambodia, Myanmar, } \\
\text { Philippines(2), Bolivia(2) }\end{array}$ & South Africa, Bangladesh & "Botswana, Indonesia (2), Palestine & Others \\
\hline & 12 & 31 & 32 & \\
\hline
\end{tabular}

* post-Tsunami in 2004 